\title{
Annotated Bibliography of Scientific Research on Ventenata dubia Published from 2010 to 2020
}

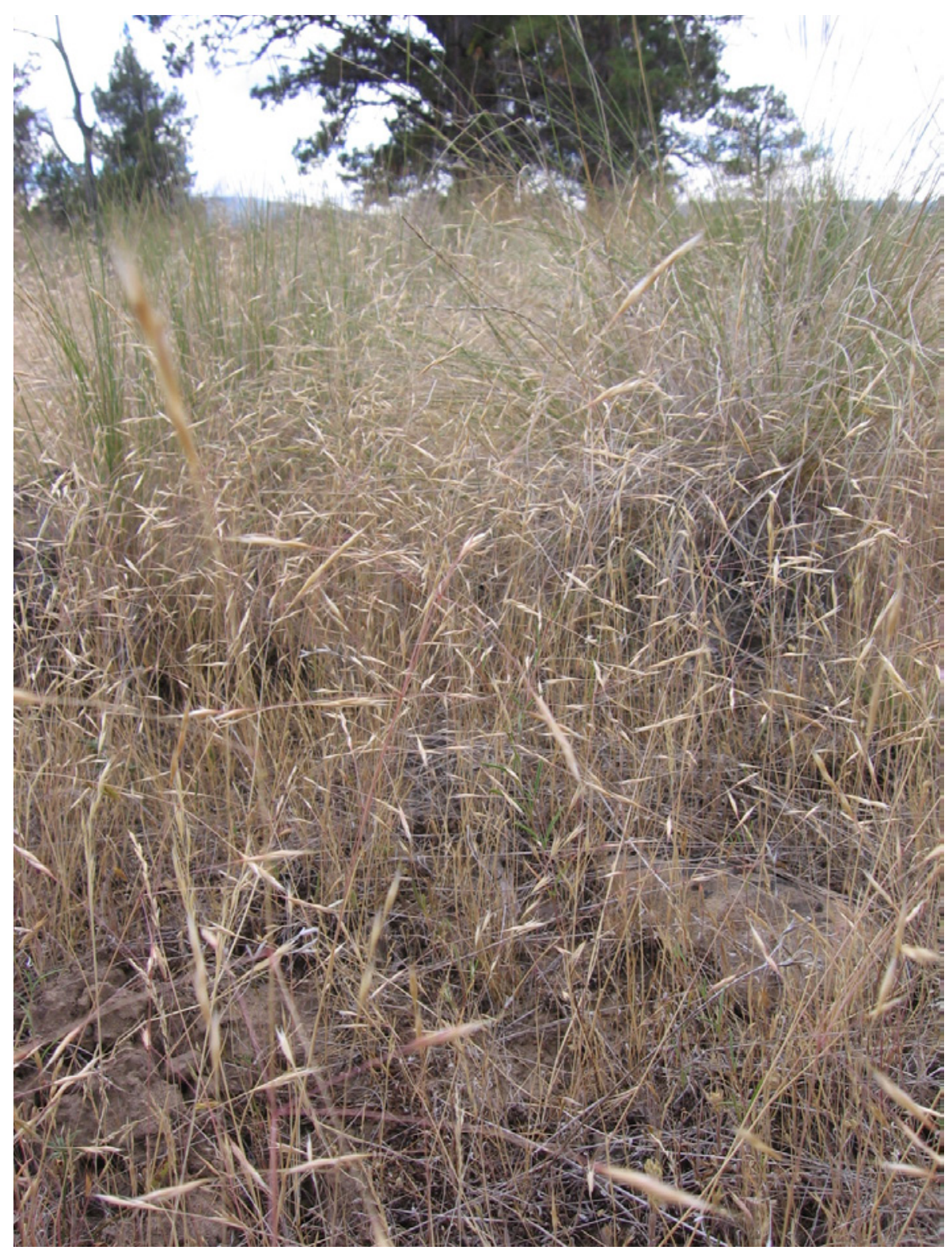

Open-File Report 2021-1031 
Cover. Photograph from Michelle Day, CC BY-SA 2.0, https://creativecommons.org/licenses/by-sa/ 2.0/deed.en. 


\section{Annotated Bibliography of Scientific Research on Ventenata dubia Published from 2010 to 2020}

By Erin E. Poor, Nathan J. Kleist, Heidi L. Bencin, Alison C. Foster, and Sarah K. Carter

Open-File Report 2021-1031 


\section{U.S. Geological Survey, Reston, Virginia: 2021}

For more information on the USGS - the Federal source for science about the Earth, its natural and living resources, natural hazards, and the environment—visit https://www.usgs.gov or call 1-888-ASK-USGS.

For an overview of USGS information products, including maps, imagery, and publications, visit https://store.usgs.gov/.

Any use of trade, firm, or product names is for descriptive purposes only and does not imply endorsement by the U.S. Government.

Although this information product, for the most part, is in the public domain, it also may contain copyrighted materials as noted in the text. Permission to reproduce copyrighted items must be secured from the copyright owner.

Suggested citation:

Poor, E.E., Kleist, N.J., Bencin, H.L., Foster, A.C., and Carter, S.K., 2021, Annotated bibliography of scientific research on Ventenata dubia published from 2010 to 2020: U.S. Geological Survey Open-File Report 2021-1031, 26 p., https://doi.org/10.3133/ofr20211031.

ISSN 2331-1258 (online) 


\section{Contents}

Abstract

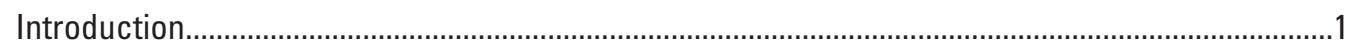

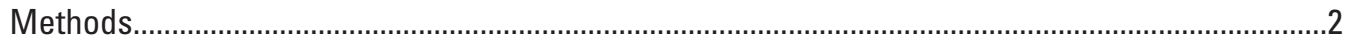

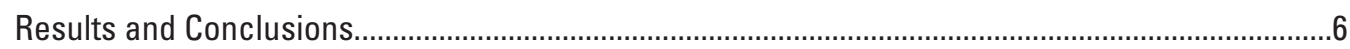

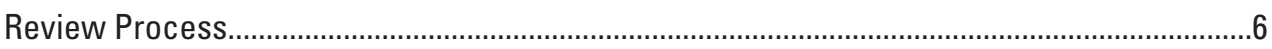

Acknowledgments

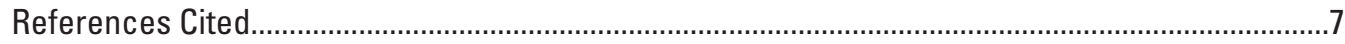

\section{Tables}

1. Management categories and topics assessed for each product included in the

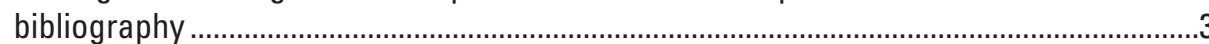

\section{Conversion Factors}

U.S. customary units to International System of Units

\begin{tabular}{|c|c|c|}
\hline Multiply & By & To obtain \\
\hline \multicolumn{3}{|c|}{ Length } \\
\hline mile (mi) & 1.609 & kilometer (km) \\
\hline \multicolumn{3}{|c|}{ Area } \\
\hline acre & 4,047 & square meter $\left(\mathrm{m}^{2}\right)$ \\
\hline acre & 0.4047 & hectare (ha) \\
\hline acre & 0.004047 & square kilometer $\left(\mathrm{km}^{2}\right)$ \\
\hline
\end{tabular}

International System of Units to U.S. customary units

\begin{tabular}{|c|c|c|}
\hline Multiply & By & To obtain \\
\hline \multicolumn{3}{|c|}{ Length } \\
\hline meter (m) & 3.281 & foot $(\mathrm{ft})$ \\
\hline kilometer (km) & 0.6214 & mile (mi) \\
\hline meter $(\mathrm{m})$ & 1.094 & yard (yd) \\
\hline \multicolumn{3}{|c|}{ Area } \\
\hline hectare (ha) & 2.471 & acre \\
\hline square kilometer $\left(\mathrm{km}^{2}\right)$ & 247.1 & acre \\
\hline hectare (ha) & 0.003861 & square mile $\left(\mathrm{mi}^{2}\right)$ \\
\hline square kilometer $\left(\mathrm{km}^{2}\right)$ & 0.3861 & square mile $\left(\mathrm{mi}^{2}\right)$ \\
\hline
\end{tabular}




\title{
Abbreviations
}

\author{
BLM Bureau of Land Management \\ DNA deoxyribonucleic acid (genetic code) \\ GPS Global Positioning System \\ USDA U.S. Department of Agriculture \\ USGS U.S. Geological Survey
}

\section{Species Names}

Common name
aphid
barley
barley or cereal yellow dwarf
bluebunch wheatgrass
cattle (domestic)
cheatgrass
downy brome
feral (cereal) rye
field brome
Japanese brome
jointed goatgrass
medusahead
North African wiregrass
red brome
sagebrush
soft brome
smooth brome
timothy
ventenata

Scientific name

Rhopalosiphum padi Linnaeus

Hordeum vulgare Linnaeus

family Luteoviridae virus

Pseudoroegneria spicata (Pursh) A. Love

Bos taurus Linnaeus

Bromus tectorum Linnaeus

Bromus tectorum Linnaeus

Secale cereal Linnaeus

Bromus arvensis Linnaeus

Bromus japonicus Thunberg

Aegilops cylindrica Host

Taeniatherum caput-medusae (Linnaeus) Nevski

Ventenata dubia (Leers) Cosson

Bromus rubens Linnaeus

Artemisia species Linnaeus

Bromus hordeaceus Linnaeus

Bromus inermus Leyss

Phleum pretense Linnaeus

Ventenata dubia (Leers) Cosson 


\title{
Annotated Bibliography of Scientific Research on Ventenata dubia Published from 2010 to 2020
}

\author{
By Erin E. Poor, Nathan J. Kleist, Heidi L. Bencin, Alison C. Foster, and Sarah K. Carter
}

\begin{abstract}
Integrating recent science into management decisions supports effective natural resource management and can lead to better resource outcomes. However, finding and accessing science information can be time consuming and costly. To assist in this process, the U.S. Geological Survey (USGS) is creating a series of annotated bibliographies on topics of management concern for western lands. Previously published reports introduced a methodology for preparing annotated bibliographies to facilitate the integration of recent, peer-reviewed science into resource management decisions. Therefore, relevant text from those efforts is reproduced here to frame the presentation. Invasive annual grasses are widely distributed throughout the western United States and threaten native ecosystems by altering fire regimes, replacing native plants, and altering grazing patterns, often with tremendous associated costs. One invasive annual grass, Ventenata dubia (hereafter, ventenata), was first introduced to the United States in the 1950s and has recently been identified as a management concern. Ventenata has a wide native geographic range, from Africa to northern Europe, and could thus potentially spread widely in the United States if left unmanaged. We compiled and summarized peer-reviewed journal articles, government reports, and data products on ventenata published between January 1, 2010, and August 27, 2020. We first conducted a systematic search of three reference databases and three government databases using the search phrase: "ventenata" OR "Ventenata dubia." We refined the initial list of products by removing (1) duplicates, (2) products not written in English, (3) publications that were not focused in North America, (4) publications that were not published as research, data products, or scientific review articles in peer-reviewed journals or as formal technical reports, and (5) products for which ventenata was not a research focus or for which the study did not present new data or findings about ventenata. We summarized each product using a consistent structure (background, objectives, methods, location, findings, and implications) and identified the management topics (for example, species and population characteristics, habitat, control and management efforts) addressed by each product. We also noted which publications included new geospatial data. The review process for this annotated bibliography included an initial internal colleague review of each summary, requesting input on each summary from an author of the original publication, and a formal peer review. Our initial searches resulted in 505 total products, of which 29 met our criteria for inclusion. Nonnative invasive plants; weed management; behavior or demographics; dispersal, spread, vectors and pathways; site-scale habitat characteristics; survival; and weed management subtopic: herbicides were the management topics most commonly addressed. The online version of this annotated bibliography will be searchable by topic, location, and year; it will also include links to each original publication, where available. The studies compiled and summarized here may inform planning and management actions that seek to maintain and restore landscapes and control nonnative invasive species across the western United States.
\end{abstract}

\section{Introduction}

Reviewing the best available science relevant to potential land management decisions and resource planning efforts is an important part of decision-making processes, helping to ensure that proposed resource management actions and decisions are as effective as possible in meeting their stated goals. However, the number of scientific publications, the restrictive access to many publications and publication databases, and the time needed to perform a comprehensive search for the best available science on any given species or topic can hinder resource managers' ability to access and consider this science in their decisions. To facilitate the integration of science into decision-making on western lands, the U.S. Geological Survey (USGS) initiated a program of work to compile and summarize recent, peer-reviewed scientific literature on a series of resources and topics of management concern. 
The distribution, spread, and impact of invasive annual grasses is one of the biggest threats to native ecosystems and species across the western United States (DiTomaso 2000). Managing and controlling invasive grasses requires synthesis and integration of knowledge about the ecology of each invasive species, and some species are better studied than others (Knezevic and others, 2002; Swanton and others, 2008). Ventenata dubia (hereafter, ventenata), first identified in Washington State in the 1950s (Barkworth and others, 2007), has been recognized relatively recently as a growing management concern. Like cheatgrass (Bromus tectorum), ventenata grows rapidly in the spring and senesces in the summer, earlier than natives, which contributes to increased dried matter and subsequently leads to increased fire risk (D'Antonio and Vitousek, 1992; Kerns and others, 2020). Ventenata invasion has been linked to decreased native plant diversity (Averett and others, 2020; Tortorelli and others, 2020), which could have negative impacts on native ecosystems in the United States (Endress and others, 2019). To date, ventenata has been identified in dry and mesic habitats throughout the West, including rangelands (Wallace and Prather, 2016), native prairie grasslands (Nyamai and others, 2011), and recently, burned dry forests (Downing and others, 2020). Ventenata's wide native distribution, from northern Africa to Finland, and tolerance of a wide range of environmental conditions (Alomran and others, 2019), indicates invasion throughout other ecosystems and regions in the United States may be possible. Despite its rapid western spread and continued invasion potential, ventenata remains relatively understudied compared to other invasive annual grasses. To aid managers in utilizing and synthesizing the existing research, we have compiled and summarized peer-reviewed literature and data products about ventenata published between January 1, 2010, and August 27, 2020.

Although this annotated bibliography does not replace the need to read the primary literature, we hope that this document will serve as a valuable reference for planners and managers responsible for making decisions about the control of ventenata and its potential impacts on natural resources in the United States. Each summary is searchable by management topic, and we provide links to the original publications to facilitate access to primary literature sources. Management of ventenata is a topic of ongoing scientific interest and management concern. As such, information in this document could be maintained and periodically updated to serve as a readily accessible, up-to-date resource for managers, planners, and policymakers who need a quick reference to recent peer-reviewed science and data about ventenata.

\section{Methods}

Previous reports (Carter and others, 2018, 2020) introduced a methodology for preparing annotated bibliographies to facilitate the integration of recent, peer-reviewed science into resource management decisions. This and future annotated bibliographies will build on that method and apply it to new species and topics of management concern on western lands. Therefore, relevant text from Carter and others $(2018,2020)$ is reproduced herein to frame the presentation. We conducted a systematic search of three citation indices (Web of Science, Scopus [accessed through the USGS Library], and Google Scholar [accessed through Publish or Perish (Harzing, 2007)], and three government publication databases (USGS ScienceBase, USGS Publications Warehouse, and U.S. Department of Agriculture Forest Service [USFS] TreeSearch) using the search phrase: "ventenata" OR "Ventenata dubia." We developed this search phrase through consultation with an interagency team of invasive-plant experts to help ensure that our searches would capture products relevant to management of the species on lands in the United States. Also, in consultation with an interagency team of invasive plant experts, we limited our search to products published since January 1, 2010, reflecting the period of research focus on this species in the United States. We conducted our final search of all databases on August 27, 2020. In a very few cases, we supplemented products identified through these initial standardized searches with products brought to our attention through other means (for example, products about ventenata shared with us by the authors we contacted to request input on the summaries of their publications; see "Review Process" section). To be included in the annotated bibliography, we required that these opportunistically obtained products met all of the same criteria described in the following paragraph.

We refined the initial list of products returned from our searches in five ways. First, we removed duplicate items. Second, we removed products that were not written in English. Third, we removed publications that were not focused in North America because our aim was to provide managers with recent published products relevant to management of ventenata in the United States. Fourth, we excluded products that were not published as research, scientific review articles, or data products in peerreviewed journals or as formal technical reports; this exclusion helped ensure that all products presented final work that had gone through a structured peer-review process. Accordingly, we excluded editorial content (such as policy perspectives and commentaries), reports without evidence of a formal peer-review process (such as project and annual reports without a technical series or volume number and a permanent digital object identifier), conference abstracts, article preprints, articles in magazines (for which there was no reference to a peer-review process), articles in journals for which we could not find evidence of a comprehensive peer-review process, theses, dissertations, manuscripts not yet in press, and books, regardless of peer-review status. We also exclude reports that provide short summaries of research projects (often when those projects are still in progress) that are intended for sharing with a broad public audience, as those research results will be published elsewhere once the studies 
are complete. Fifth, we retained only those publications for which ventenata was a main focus and for which the publication provided new data or findings about ventenata (for original research articles) or summarized or synthesized existing data about ventenata (for review papers). This was primarily accomplished by requiring that "ventenata" or "Ventenata dubia" be present in the publication title, abstract, or author-supplied keywords (when available), and be present in the main text of the article. Publications removed using this step often only mentioned ventenata as a comparison species in the introduction or discussion and included publications about grasses in the same family, publications focused on clarifying taxonomic relationships among grasses, or publications that described a new grass parasite, for example. For large publications (for example, hundreds of pages) covering multiple topics and species, we explicitly confine our summaries to the species of interest and state this in the summary itself. Similarly, for products such as paleontological publications or review papers that cover a broad range of species, some of which may not be extant in North America, summaries note the full range of taxa covered in the publication but focus on those species that are of present day management concern in North America. In a very small number of cases, a product did present new data or findings about ventenata but did not contain "ventenata" or "Ventenata dubia" in the publication title, abstract, or author-supplied keywords. When such articles were identified or opportunistically brought to our attention, we included them in the bibliography. We cannot guarantee that our search process identified all of these products, particularly for journals which do not have keywords or for which keywords are not indexed by Web of Science or Scopus. However, we made every effort to identify these articles through Google Scholar.

Google Scholar indexes a wider range of products than the other search engines and thus required slightly different methods. Many of the Google Scholar search results were not published products, were not written in English, or did not focus on systems in North America. Thus, for the Google Scholar search, we used R (R Core Team, 2020) to iteratively filter search

Table 1. Management categories and topics assessed for each product included in the bibliography.

\begin{tabular}{|c|c|c|}
\hline Management category & Management topic & Definition \\
\hline \multirow[t]{5}{*}{$\begin{array}{l}\text { Species and population } \\
\text { characteristics }\end{array}$} & Survival & $\begin{array}{l}\text { Study quantified survival rates for plant or animal species, often in relation to } \\
\text { environmental conditions. For plants, this includes quantification of seed } \\
\text { longevity and viability. }\end{array}$ \\
\hline & Behavior or demographics & $\begin{array}{l}\text { Study measured or modeled aspects of behavior or demographics for plant } \\
\text { or animal species (for example, seasonal movements, seeds per plant, seed } \\
\text { mass, seed germination rate, vegetative reproduction, reproductive success, } \\
\text { vital rates). }\end{array}$ \\
\hline & Captive breeding & $\begin{array}{l}\text { Study developed methods for or evaluated the success of species captive breed- } \\
\text { ing efforts. For plant species, this could include greenhouse breeding. Where } \\
\text { this topic applies, "Location" refers to that of the wild population, not the } \\
\text { breeding facility. }\end{array}$ \\
\hline & $\begin{array}{l}\text { Dispersal, spread, vectors, } \\
\text { and pathways }\end{array}$ & $\begin{array}{l}\text { Study addressed species dispersal abilities, invasiveness, or factors impacting } \\
\text { spread. }\end{array}$ \\
\hline & $\begin{array}{l}\text { Other: Species and population } \\
\text { characteristics }\end{array}$ & $\begin{array}{l}\text { Study is focused on another aspect of species biology or ecology not listed } \\
\text { elsewhere. }\end{array}$ \\
\hline \multirow[t]{2}{*}{ Habitat } & $\begin{array}{l}\text { Broad-scale habitat } \\
\text { characteristics }\end{array}$ & $\begin{array}{l}\text { Study addressed landscape-level habitat characteristics (for example, size, } \\
\text { number, or connectivity of habitat patches, characteristics of linkage areas, } \\
\text { effects of landscape context on habitat quality, availability or use of seasonal } \\
\text { habitats), usually across large areas. }\end{array}$ \\
\hline & $\begin{array}{l}\text { Site-scale habitat } \\
\text { characteristics }\end{array}$ & $\begin{array}{l}\text { Study addressed habitat characteristics at the local level (for example, nest } \\
\text { sites or brood-rearing areas for wildlife species), typically based on field } \\
\text { measurement of vegetation or soils. }\end{array}$ \\
\hline
\end{tabular}


Table 1. Management categories and topics assessed for each product included in the bibliography.-Continued

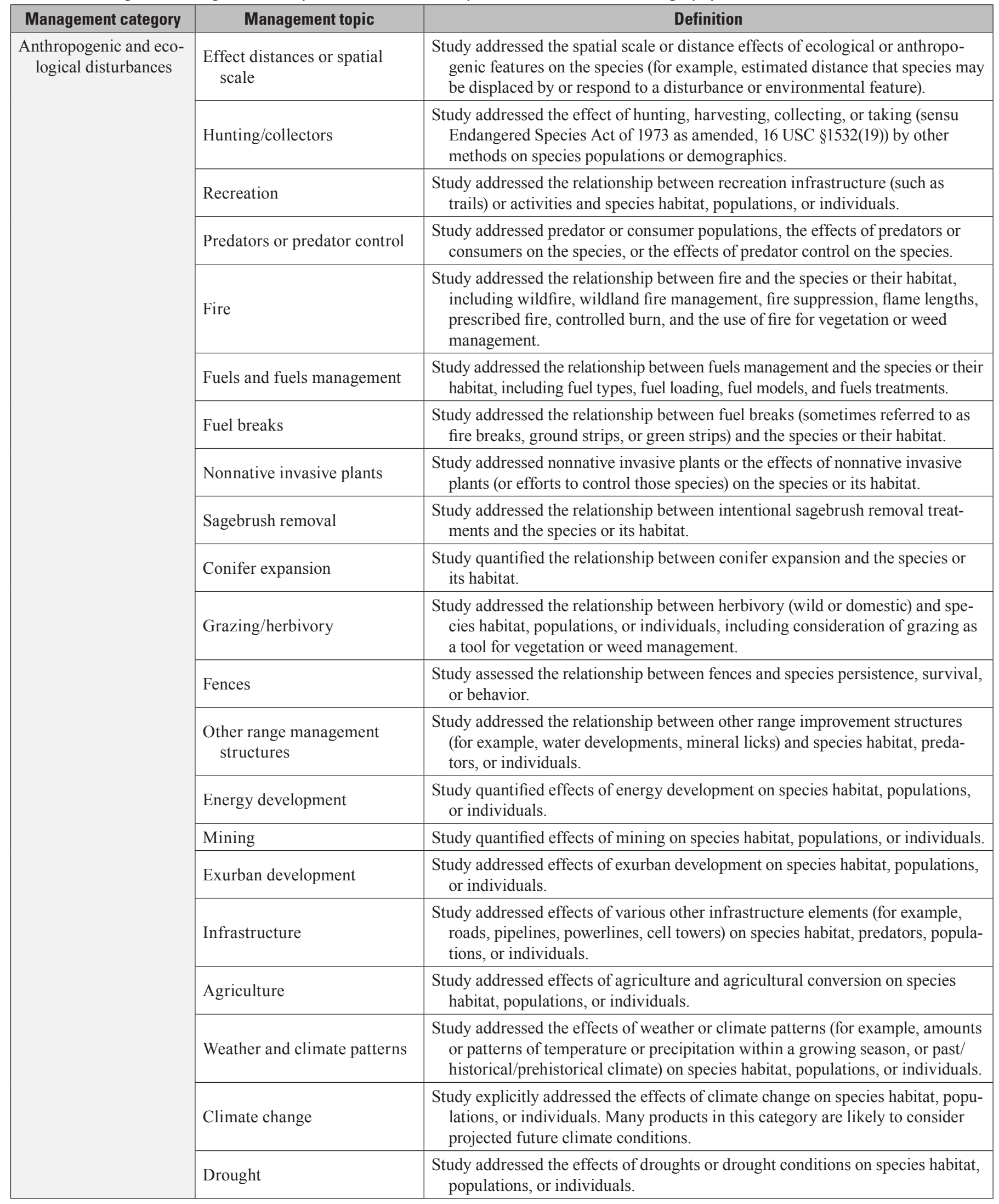


Table 1. Management categories and topics assessed for each product included in the bibliography.-Continued

\begin{tabular}{|c|c|c|}
\hline Management category & Management topic & Definition \\
\hline \multirow[t]{4}{*}{$\begin{array}{l}\text { Invasive plant control or } \\
\text { management efforts }\end{array}$} & Weed management & $\begin{array}{l}\text { Study addressed some aspect of weed management, which may include methods } \\
\text { for controlling the abundance or spread of noxious weeds or nonnative inva- } \\
\text { sive plants or assessed the effectiveness of weed control efforts. }\end{array}$ \\
\hline & Subtopic: Biocontrol & $\begin{array}{l}\text { Study addressed invasive plant control efforts that use one or more species of } \\
\text { introduced agent (for example, predator, herbivore, pathogen) from the target } \\
\text { species' native range. }\end{array}$ \\
\hline & Subtopic: Herbicides & Study addressed invasive plant control efforts that use chemical agents. \\
\hline & $\begin{array}{l}\text { Subtopic: Mechanical vegeta- } \\
\text { tion removal }\end{array}$ & $\begin{array}{l}\text { Study addressed invasive plant control efforts that consist of mechanical removal } \\
\text { using methods like hand pulling, removal with tools like loppers, girdling, } \\
\text { shredding, hoeing, bulldozing or the use of other heavy equipment, tillage, } \\
\text { cultivation, or mowing. }\end{array}$ \\
\hline \multirow{8}{*}{$\begin{array}{l}\text { Relationships with other } \\
\text { resources }\end{array}$} & Water & $\begin{array}{l}\text { Study addressed the relationship between species habitat, populations, or indi- } \\
\text { viduals and water resources (for example, groundwater, surface water, hydrol- } \\
\text { ogy, water quantity or quality, or water rights). }\end{array}$ \\
\hline & Soils or geology & $\begin{array}{l}\text { Study addressed the relationship between species habitat, populations, or indi- } \\
\text { viduals and soils or geology, including biological soil crusts. }\end{array}$ \\
\hline & $\begin{array}{l}\text { Cultural, historical, Native } \\
\text { American, or archaeologi- } \\
\text { cal sites or values }\end{array}$ & $\begin{array}{l}\text { Study addressed cultural, historical, archaeological, or Native American re- } \\
\text { sources. }\end{array}$ \\
\hline & $\begin{array}{l}\text { Public health, safety, or en- } \\
\text { forcement }\end{array}$ & $\begin{array}{l}\text { Study addressed public health or safety, or the enforcement of laws, statutes, or } \\
\text { other regulations. }\end{array}$ \\
\hline & Wetlands/riparian & $\begin{array}{l}\text { Study addressed the relationship between species habitat, populations, or indi- } \\
\text { viduals and wetland or riparian areas. }\end{array}$ \\
\hline & Sensitive/rare wildlife & $\begin{array}{l}\text { Study addressed one or more sensitive, rare, or protected wildlife species, includ- } \\
\text { ing insects. }\end{array}$ \\
\hline & Sensitive/rare fish & Study addressed one or more sensitive, rare, or protected fish species. \\
\hline & Sensitive/rare plants & Study addressed one or more sensitive, rare, or protected plant species. \\
\hline \multirow[t]{2}{*}{ Other } & Includes new geospatial data & $\begin{array}{l}\text { Study makes publicly available newly created geospatial data relevant to species } \\
\text { policy, planning, or management. }\end{array}$ \\
\hline & $\begin{array}{l}\text { Human dimensions or eco- } \\
\text { nomics }\end{array}$ & $\begin{array}{l}\text { Study addressed the human dimensions or economics of species policy, plan- } \\
\text { ning, or management. }\end{array}$ \\
\hline
\end{tabular}


results based on metadata provided by Google Scholar. We first removed products of type "citation" and then used identifiers in the uniform resource locator (URL) to remove products that were books, book chapters, patents, theses, or dissertations. We flagged products that included text in the abstract or title that was identified as a language other than English by either of two methods of language detection (Ooms, 2018; Ooms, 2020). To ensure accurate results, we screened the abstracts and titles of flagged non-English products (Westgate, 2019) and reintegrated those that could not be reliably excluded by language recognition. We then excluded products from URLs that did not have a top-level domain of .com, .edu, .org, .us, .gov, .net, .ca, .uk, or info. Finally, we removed articles from any journals known to not meet our standards for peer review. We manually filtered the remaining articles so that our final list of products to be included in the annotated bibliography met all criteria described above.

We parsed the final list of publications among our group of scientists to develop summaries of each product. The scientist to which the publication had been assigned then read each publication, summarized its contents using a consistent structure (background, objectives, methods, location, findings, implications), and identified the management topics it addressed (table 1). Location information included the State(s) and, where applicable, the general area within each State. For studies involving translocated individuals or individuals held, studied, or bred in captive facilities or greenhouses, the location information reflects the release location or the location of collection. The site of the captive/greenhouse facility is not included as part of the location information in our product summaries but can be found in the original published product. Considerable information was distilled from each publication in developing the summary, and for products that include data and findings for several species, these summaries may focus on the species of interest to the annotated bibliography. Thus, though we accurately represent each publication, there may be additional information in the original product that is not included in each summary. The target length for summaries was short (250-350 words); as a result, the source documents should always be consulted directly for more specific information (links to the original publication are provided for each summary). Each initial summary, and the associated original publication, was then reviewed by another scientist in the group to promote consistency between summaries and to provide an additional check on the accuracy of summaries in capturing key findings from the original publication.

\section{Results and Conclusions}

In our initial searches, we identified a total of 505 products: 21 products from Web of Science, 22 from Scopus, 0 from the USGS Publications Warehouse, 3 from ScienceBase, 1 from the USFS TreeSearch, and 458 from Google Scholar (published products and unpublished products). For Google Scholar, using the automated filtering methods with R described in the "Methods" section above, we manually filtered 238 products based on our inclusion criteria. After conducting our initial search and requesting input from authors, two additional products were brought to our attention that fit our criteria for inclusion but were not found during the initial search. We included these products opportunistically. After removing duplicates, publications not written in English, publications that were not peer reviewed, publications focused outside of North America, and publications that did not present new data or focus on ventenata, we retained 29 peer-reviewed published science and data products.

These 29 products addressed 27 of the 52 management topics. Every product addressed nonnative invasive plants. Eleven products ( 38 percent) addressed weed management. Nine products ( 31 percent) addressed behavior or demographics; dispersal, spread, vectors, and pathways; and site-scale habitat characteristics. Seven products ( 24 percent) addressed survival and the weed management subtopic: herbicides. Ten products ( 35 percent) included new geospatial data. Only two products ( 7 percent) addressed climate change, population estimates or targets, soils or geology, and water. One product (3 percent) addressed captive breeding, fuels and fuels management, genetics, grazing/herbivory, other species or population characteristics, predators or predator control, and weed management subtopic: biocontrol.

These studies are the recent (since 2010) body of published, peer-reviewed articles, reports, and data products that are written in English and focus on Ventenata dubia in North America. We present this annotated bibliography as a resource for managers to easily access and integrate this information into their decisions. As ventenata and other invasive annual grasses are of growing management concern, this annotated bibliography may be updated periodically to incorporate new knowledge.

\section{Review Process}

In addition to our internal, colleague review, we conducted external reviews. This process was twofold and included (1) requesting input on each summary from one or more authors of the original peer-reviewed publication, and (2) a formal review of the entire document by two independent reviewers and by the USGS Bureau Approving Official. This process is consistent with USGS Fundamental Science Practices (Fundamental Science Practices Advisory Committee, 2011). 


\section{Acknowledgments}

We thank John (Dell) Long with the Decision Support Science and Tools branch of the Fort Collins Science Center for assistance with conducting the literature search. We are appreciative of the input and guidance of Michele Crist, Lindy Garner, Travis Haby, Julie Heinrichs, John Tull, and Lief Wiechman. We thank the many authors of publications summarized within this annotated bibliography for providing input on the draft article summaries, including Sheel Bansal, Stephen Boyte, Kirk Davies, Will Downing, Laura Ingwell, Lisa Jones, Lesley Morris, Timothy Prather, Matt Rinella, Thomas Rodhouse, Claire Tortorelli, and John Wallace. We are very grateful to Becky Kerns, Rebecca Lemons, Brian Mealor, and Claire Tortorelli for providing independent peer review of the entire report and the summaries it contains.

Funding for this work was provided by the Bureau of Land Management, the U.S. Fish and Wildlife Service, and the U.S. Geological Survey Ecosystems Mission Area. Any use of trade, firm, or product names is for descriptive purposes only and does not imply endorsement by the U.S. Government.

\section{References Cited}

Averett, J.P., Morris, L.R., Naylor, B.J., Taylor, R.V., and Endress, B.A., 2020, Vegetation change over seven years in the largest protected Pacific Northwest bunchgrass prairie remnant: PLoS One, v. 15, no. 1, p. e0227337. [Also available at https://doi.org/10.1371/journal.pone.0227337.]

Barkworth, M.E., Capels, K.M., and Long, S., eds., 2007, v. 24. Magnoliophyta: Commelinidae (in part): Poaceae, part 1: North of Mexico, Flora of North America: New York, Oxford, Oxford University Press, 944 p.

Carter, S.K., Arkle, R.S., Bencin, H.L., Harms, B.R., Manier, D.J., Johnston, A.N., Phillips, S.L., Hanser, S.E., and Bowen, Z.H., 2020, Annotated bibliography of scientific research on greater sage-grouse published since January 2015: U.S. Geological Survey Open-File Report 2018-1008, 183 p., https://doi.gov/10.3133/ofr20201103.

Carter, S.K., Manier, D.J., Arkle, R.S., Johnston, A.N., Phillips, S.L., Hanser, S.E., and Bowen, Z.H., 2018, Annotated bibliography of scientific research on greater sage-grouse published since January 2015: U.S. Geological Survey Open-File Report 2018-1008, 183 p. [Also available at https://doi.org/10.3133/ofr20181008.]

D'Antonio, C.M., and Vitousek, P.M., 1992, Biological invasions by exotic grasses, the grass/fire cycle, and global change: Annual Review of Ecology and Systematics, v. 23, no. 1, p. 63-87, accessed January 22, 2021, at https://doi.org/10.1146/ annurev.es.23.110192.000431.

DiTomaso, J.M., 2000, Invasive weeds in rangelands-Species, impacts, and management: Weed Science, v. 48, no. 2, p. 255-265, accessed January 22, 2021, at https://doi.org/10.1614/0043-1745(2000)048[0255:IWIRSI]2.0.CO;2.

Downing, W.M., Krawchuk, M.A., Coop, J.D., Meigs, G.W., Haire, S.L., Walker, R.B., Whitman, E., Chong, G., Miller, C., and Tortorelli, C., 2020, How do plant communities differ between fire refugia and fire-generated early-seral vegetation?: Journal of Vegetation Science, v. 31, no. 1, p. 26-39, accessed January 22, 2021, at https://doi.org/10.1111/jvs.12814.

Endress, B.A., Averett, J.P., Naylor, B.J., Morris, L.R., and Taylor, R.V., 2019, Nonnative species threaten the biotic integrity of the largest remnant Pacific Northwest bunchgrass prairie in the United States: Applied Vegetation Science, v. 23, p. $23-53$.

Fundamental Science Practices Advisory Committee, 2011, U.S. Geological Survey Fundamental Science Practices: U.S. Geological Survey Circular 1367, 8 p.

Harzing, A.W., 2007, Publish or perish: Harzing, Research in International Management software release, accessed August 27, 2021, at https://harzing.com/resources/publish-or-perish

Kerns, B.K., Tortorelli, C., Day, M.A., Nietupski, T., Barros, A.M.G., Kim, J.B., and Krawchuk, M.A., 2020, Invasive grasses-A new perfect storm for forested ecosystems?: Forest Ecology and Management, v. 463, p. 117985, accessed January 22, 2021, at https://doi.org/10.1016/j.foreco.2020.117985.

Knezevic, S.Z., Evans, S.P., Blankenship, E.E., Van Acker, R.E., and Lindquist, J.L., 2002, Critical period for weed controlThe concept and data analysis: Weed Science, v. 50, no. 6, p. 773-786, accessed January 22, 2021, at https://doi.org/10.1614/ 0043-1745(2002)050[0773:CPFWCT]2.0.CO;2. 
Nyamai, P.A., Prather, T.S., and Wallace, J.M., 2011, Evaluating restoration methods across a range of plant communities dominated by invasive annual grasses to native perennial grasses: Invasive Plant Science and Management, v. 4, no. 3, p. 306-316, accessed January 22, 2021, at https://doi.org/10.1614/IPSM-D-09-00048.1.

Ooms, J., 2018, cld2 - Google's Compact Language Detector 2, R package (ver. 1.2): R Project for statistical computing software release, accessed August 27, 2021, at https://CRAN.R-project.org/package=cld2

Ooms, J., 2020, cld3 - Google's Compact Language Detector 3, R package (ver. 1.3): R Project for Statistical Computing software release, accessed August 27, 2021, at https://CRAN.R-project.org/package=cld3

R Core Team, 2020, R-A language and environment for statistical computing: Vienna, Austria, R Foundation for Statistical Computing software release, accessed August 27, 2021, at https://www.R-project.org/

Swanton, C.J., Mahoney, K.J., Chandler, K., and Gulden, R.H., 2008, Integrated weed management—Knowledge-based weed management systems: Weed Science, v. 56, no. 1, p. 168-172, accessed January 22, 2021, at https://doi.org/10.1614/WS-07-126.1.

Wallace, J.M., and Prather, T.S., 2016, Herbicide control strategies for Ventenata dubia in the intermountain Pacific Northwest: Invasive Plant Science and Management, v. 9, no. 2, p. 128-137, accessed January 22, 2021, at https://doi.org/ 10.1614/IPSM-D-16-00017.1.

Westgate, M.J., 2019, revtools-An R package to support article screening for evidence synthesis: Research Synthesis Methods, v. 10, no. 4, p. 606-614, accessed August 27, 2021, at https://doi.org/10.1002/jrsm.1374. 


\title{
Annotated Bibliography of Scientific Research on Ventenata dubia Published from 2010 to 2020
}

\author{
Alomran, M., Newcombe, G., and Prather, T., 2019, Ventenata dubia's native range and \\ consideration of plant pathogens for biological control: Invasive Plant Science and \\ Management, v. 12, no. 4, p. 242-245.
}

Background: Ventenata has been found to be problematic in North America relatively recently. Although ventenata has negative impacts across the western United States, populations in its native range appear to be well controlled by native pathogens. Knowledge of ventenata's native latitudinal distribution will aid in prediction of its potential spread within North America and guide study of potential biological control agents.

DOI: https://doi.org/10.1017/inp.2019.24

Objectives: The authors investigated (1) the distribution of ventenata across its native range, (2) evidence of pathogens in populations in the Pacific Northwest, and (3) fungi that have been observed on ventenata.

Methods: Ventenata plants were sampled for evidence of disease in samples collected from 41 sites in Washington, Oregon, Idaho, and Montana in 2014 and a population in Idaho observed from 2016 to 2018. The authors also searched geographic records including herbarium specimens for evidence of ventenata's current and historical distribution.

Location: Idaho, Montana, Oregon, Washington

Findings: The authors found no evidence of pathogens on their collected samples or in the Idaho population. Records of ventenata found it to be prevalent throughout Europe and present in North Africa and southwest Asia, with select populations in Europe in lower abundances.

Implications: Given ventenata's wide native range from Finland to Morocco, it is expected to expand in North America where there is no evidence of pathogens to serve as a natural control. The authors suggest that pathogens present in European populations may serve as potential control for ventenata given the rare and endangered status of populations in parts of Europe where natural controls exist.

Topics: behavior or demographics; dispersal, spread, vectors, and pathways; nonnative invasive plants; weed management; weed management subtopic: biocontrol

\section{Averett, J.P., McCune, B., Parks, C.G., Naylor, B.J., Delcurto, T., and Mata-Gonzalez, R., 2016, Non-native plant invasion along elevation and canopy gradients in a middle Rocky Mountain ecosystem: PLoS One, v. 11, no. 1, p. e0147826.}

DOI: https://doi.org/10.1371/journal.pone.0147826

Background: Invasive species are a main threat to biodiversity. Mountain environments, though one of the least invaded ecosystems, are beginning to see higher prevalence of invasive species. Expansion of invasive species to mountain systems may increase with climate change and human activities. In northeastern Oregon, factors influencing nonnative versus native plant elevation patterns are not well understood.

Objectives: The authors aimed to determine (1) which habitats were most invaded by nonnative plants, (2) how environmental factors impact nonnatives and natives across elevations, (3) which factors predict richness and abundance of natives and nonnatives, and (4) whether nonnative plants in this ecosystem have specializations for high elevations or closed-canopy forests. 
Methods: The authors sampled vascular plant species abundance and environmental factors at 20 locations along each of 3 roads that traversed elevational gradients in the summer of 2012. They collected climate, topographical, and soils data from online sources. Using community ecology statistics, they assessed nonnative species occurrence, factors influencing plant distribution along the elevational gradient, factors associated with plant species, and whether nonnative plants showed special adaptation to mountain ecosystems.

Location: northeastern Oregon

Findings: The authors identified 385 species, about one-fifth of which were nonnative. Nonnative species were found most in grass shrubland and least in subalpine habitats. The authors identified medusahead and ventenata as the most abundant species in grass shrubland habitat. They identified nonnative species more frequently at low and mid elevation sites with open canopies. Native species varied with canopy cover and elevation. Decreasing elevation most strongly predicted nonnative species richness and abundance, while 30-year minimum temperature predicted native species richness and abundance. Almost all nonnative species had optimal habitat conditions within low-mid elevation open-canopy areas.

Implications: The authors suggest that their findings support the hypothesis that invasions begin at low elevations and spread until nonnative species reach a physiological or ecological barrier. The authors suggest more research should focus on ventenata invasion dynamics and impacts. The authors state that restoration of canopy openness in montane forests could result in nonnative plant establishment and should include monitoring for invasive species.

Topics: dispersal, spread, vectors, and pathways; broad-scale habitat characteristics; site-scale habitat characteristics; nonnative invasive plants

\section{Averett, J.P., Morris, L.R., and Endress, B.A., 2020a, Dataset of plant composition change over seven years at the Zumwalt Prairie Preserve, Oregon, USA: Data in Brief, v. 29, p. 105104.}

DOI: https://doi.org/10.1016/j.dib.2019.105104

Background: Annual exotic grasses have begun to invade prairie remnants within the Pacific Northwest, which is an understudied vegetation type with high conservation value.

Objectives: The authors aimed to provide: (1) spreadsheets of plant species abundance, (2) boxplots of change in plant foliar cover, and (3) plots of ventenata abundance as support for the research article: Averett and others (2020b).

Methods: The authors sampled 124 one-hectare plots over a 7-year period, sampling in either 2008 and 2015 or 2009 and 2016. Plots were classified as old fields, xeric prairie, or mesic prairie, and the authors sampled prairie lands but not canyon lands. The authors estimated foliar cover and frequency of dominant nonnative grass species, which they used to calculate change in abundance of species.

Location: northeastern Oregon

Findings: The authors present their data describing changes in species cover for 30 dominant vascular plants, the frequency of nonnative species for each of the three plot types, and the geographic locations where there was the greatest change in ventenata abundance. They provide geographic and ecological plots of ventenata abundance. The authors present their full scientific results in Averett and others (2020b).

Implications: The authors suggest the data provided here can be used in conservation and restoration efforts involving exotic annual grasses as they provide data from an early stage of invasion. These data can also be compared to future repeat measurements to measure future impacts of invasion.

Topics: behavior or demographics; nonnative invasive plants; protected lands or areas; includes new geospatial data 


\title{
Averett, J.P., Morris, L.R., Naylor, B.J., Taylor, R.V., and Endress, B.A., 2020b, Vegetation change over seven years in the largest protected Pacific Northwest bunchgrass prairie remnant: PLoS One, v. 15, no. 1, p. e0227337.
}

\author{
DOI: https://doi.org/10.1371/journal.pone.0227337
}

Background: North American grasslands are one of the most human-modified ecosystems, and nonnative plants are one of the most significant threats to these ecosystems. The invasion of nonnative plants, such as ventenata, can result in native species composition and function changes. Although ventenata has been in eastern Oregon prairies since the 1980s, its biology and impact on native plants has not been well studied in this ecosystem.

Objectives: The authors (1) identified plant community composition change across time in three plant communities, (2) determined which plant species had the largest change in abundance, and (3) determined how abundance of ventenata related to that of native and other nonnative plants.

Methods: In the summers of 2015 and 2016, the authors resampled composition, cover, and frequency of common plant species at 150 points within 124 permanent plots in xeric, mesic, and old field sites across a preserved prairie, originally sampled in 2008 and 2009. Using models, the authors compared changes in species composition and cover across time, identified species likely driving changes, and evaluated the relationship of ventenata to other plants within communities.

Location: northeastern Oregon

Findings: Vegetation composition changed in all communities. In old fields, native grasses and ventenata increased. In mesic areas, native forbs decreased while nonnative plants increased, and in xeric areas, some nonnative grasses, including ventenata and native perennial forb species, decreased. While the two dominant native species' cover and frequency remained consistent, ventenata became one of the most dominant species across the study area in each community type. The relationship of ventenata and native perennial grasses was inconsistent across time, but ventenata was negatively related to perennial forb cover. Data are provided in Averett and others (2020a) and summarized in this annotated bibliography.

Implications: The authors suggest cultivation legacies may increase the spread of nonnative grasses but note that ventenata does not need previously cultivated areas to spread. Restoration of old fields may expose bare ground, leading to ventenata invasion. The authors were unable to draw causal relationships between increased ventenata and decreased native forbs and suggest additional research is needed in native grasslands to better understand ventenata and prevent further spread.

Topics: site-scale habitat characteristics; habitat selection; nonnative invasive plants; agriculture; protected lands or areas; includes new geospatial data

\section{Bansal, S., James, J.J., and Sheley, R.L., 2014, The effects of precipitation and soil type on three invasive annual grasses in the western United States: Journal of Arid Environments, v. 104, p. 38-42.}

DOI: https://doi.org/10.1016/j.jaridenv.2014.01.010

Background: While cheatgrass has been the focus of many studies, little is known about the response of other invasive annual grasses such as medusahead and ventenata to environmental variables. Future climate projections suggest that patterns of water availability may shift, possibly affecting invasive species' success differently. Each invasive annual grass species has a unique environmental impact; thus, it is important to understand these differences.

Objectives: The authors aimed to determine how cheatgrass, medusahead, and ventenata differ in their responses to various moisture regimes and soil characteristics.

Methods: The authors collected soil from nine random sites within the study area and determined their composition. They used two watering regimes simulating small frequent rains and large infrequent rains and used the same amount of water for each. In a growth chamber, the authors tested every treatment combination between the three grasses, nine soil types, and two watering regimes, with four replicates of each treatment over two trials. Finally, the authors measured and compared soil moisture and plant biomass within and among species and treatments. 
Location: eastern Oregon

Findings: The three species responded similarly to water regimes and soil characteristics. Soil moisture was greatest in treatments with large infrequent watering regimes, where ventenata was grown, or in clay soils. Cheatgrass and ventenata growth did not differ with either watering regime, but medusahead growth responded positively to the large infrequent watering regime. Medusahead had the greatest root growth across all soil and watering regimes. Soil properties affected plant biomass more than water regimes, and shoot growth varied more than root growth, but there were no interactions between soil and species.

Implications: Because medusahead had more root biomass and exhibited greater root growth in response to environmental manipulations, it may have a competitive advantage over cheatgrass and ventenata. Medusahead may be able to spread faster in comparison under projected future climate scenarios. The authors suggest further research to investigate the interactions of soil properties and precipitation on plant growth to better understand their roles. The authors also suggest that their findings rationalize the use of one functional group for these three species when making broad-scale assessments in sagebrush-steppe habitat.

Topics: survival; population estimates or targets; broad-scale habitat characteristics; nonnative invasive plants; weather and climate patterns; climate change; water; soils or geology; includes new geospatial data

\title{
Bernards, S.J., and Morris, L.R., 2017, Comparisons of canyon grassland vegetation and seed banks along an early successional gradient: Northwest Science, v. 91, no. 1, p. 27-40.
}

\author{
DOI: https://doi.org/10.3955/046.091.0105
}

Background: Cultivation of grasslands often leads to introduction of exotic species and degradation of native communities. The seed bank serves as a regenerative source for plant communities following disturbance and is important for the future trajectory of the community. Native perennial grasses do not form persistent seed banks, but invasive annual grasses form seed banks that can dominate previously cultivated fields for decades.

Objectives: The authors aimed to evaluate the relationship between the seed bank and aboveground vegetation, successional stage, and historical cultivation.

Methods: The authors performed field work during June and July 2014. They established eight sites to examine the relationship between the seed bank, aboveground vegetation, and successional stage. In another field study, the authors used four sites that had been cultivated and two reference sites to explore the effects of historical cultivation on the seed bank. They surveyed aboveground vegetation and collected soil core samples, which were transferred to a greenhouse and identified to species following germination to determine density of each species in the seed bank.

Location: northeastern Oregon

Findings: Aboveground cover of perennial species at the field sites was more abundant than annual species, but the germinated seeds from the soil samples suggest that the seed bank was primarily composed of annual species. The relationship between the seed bank and extant aboveground vegetation was strongest in the earliest successional stages and was driven by the presence of ventenata. This annual grass-dominated successional stage contained the highest cover of introduced grasses and lowest amount of native grasses and forbs. Density of seedling invasive grasses was significantly higher in cultivated versus noncultivated sites.

Implications: The authors suggest that these sites may be native-seed limited and could shift to invasive-species dominance following disturbance. This may be more likely in habitats that have been previously cultivated. They suggest that studying the seed bank dynamics of ventenata may help managers better understand how this species will respond to disturbance. The authors also note that their study, which was performed in early summer, may not have effectively sampled the transient seed bank.

Topics: behavior or demographics; nonnative invasive plants; agriculture 


\title{
Bernards, S.J., and Morris, L.R., 2017, Influence of topography on long-term successional trajectories in canyon grasslands: Applied Vegetation Science, v. 20, no. 2, p. 236-246.
}

\author{
DOI: https://doi.org/10.1111/avsc.12272
}

Background: Topography, disturbance, and soils can influence the distribution of species in grassland communities. Prior studies identified discrete community types and seral stages within the canyon grassland system using classical successional models. Though decline of native bunchgrasses in flatter areas is thought to be due to easy accessibility and land use, effects of disturbance and topography on grassland community structure and succession has seen little study.

Objectives: The authors sought to (1) investigate successional change over time, (2) examine differences in species composition within seral stages over time, and (3) determine which topographic variables were associated with changes in vegetation over time.

Methods: In 2014, the authors resampled 19 of 250 plots within 9 of 34 sites originally surveyed in 1987 in a National Recreation Area. Within these plots the authors collected data on topography and frequency of individual plant species. The authors classified and validated seral stages for 9 plant associations using data from the 2014 resample. The authors analyzed changes in species composition over time and associations between seral stages and topographic variables.

Location: northeastern Oregon

Findings: Seral stages within plant associations at most plots stayed the same or moved to a later seral stage, though eight plots moved to an earlier seral stage. Notably, ventenata was not recorded in the 1987 survey. A new seral stage classification, "annual grass dominated," was created in 2014 to account for the presence and abundance of ventenata and other exotic annual grasses. Seral stage changes were related to topography within plots, with areas characterized by lower slope angles more commonly transitioning to annual grass dominated or early seral stages.

Implications: The authors found that topography may serve as a proxy for land use, impact changes in plant associations, and play a role in the spread of exotic species. Specifically, the authors suggest that the greatest topographical concern for ventenata is on benchlands, or areas with slopes less than 20 degrees. The authors suggest that ventenata occurs in multiple grassland associations and primarily early seral stages, distinguishing it from other exotic grasses that are commonly found at all seral stages.

Topics: broad-scale habitat characteristics; site-scale habitat characteristics; nonnative invasive plants

\section{Boyte, S.P., and Wylie, B.K., 2018, Early estimates of herbaceous annual cover in the sagebrush ecosystem (May 1, 2018): U.S. Geological Survey data release.}

DOI: https://doi.org/10.5066/P9KSR9Z4

Background: Invasive annual grasses are prevalent in the Great Basin of the United States. These grasses provide novel fuels in the sagebrush ecosystem, thereby aiding in fire ignition and contributing to sagebrush fragmentation.

Objectives: The authors aimed to provide an early season estimate of annual herbaceous cover for early 2018.

Methods: The authors used MODIS satellite imagery through May 1, 2018, ground-truth data of annual herbaceous percent cover, geophysical variables, and statistical software to estimate annual herbaceous cover at 250 meters $(\mathrm{m})$ resolution below $2,250 \mathrm{~m}$ in elevation.

Location: eastern California, Colorado, southern Idaho, southern Montana, western Nebraska, Nevada, eastern Oregon, western South Dakota, Utah, Wyoming

Findings: The authors created a spatially explicit dataset of early season herbaceous annual percent cover for the Great Basin at $250 \mathrm{~m}$ resolution. The authors identified cheatgrass as the most common annual grass in the study area, followed by red brome, medusahead, and ventenata.

Implications: These data can provide managers and scientists with spatially explicit, early spring, near-real-time estimates of annual vegetation cover for management and research purposes and should be used as relative abundance. However, the authors note the results found in this early season dataset may differ from those found later in the season, and this dataset may be improved by future mapping efforts. Additionally, this dataset is large in spatial scale, which may contribute to potential differences between this and other datasets of different spatial resolutions.

Topics: nonnative invasive plants; includes new geospatial data 


\section{Boyte, S.P., and Wylie, B.K., 2018, Near-real-time herbaceous annual cover in the sagebrush ecosystem, USA, July 2018: U.S. Geological Survey data release.}

DOI: https://doi.org/10.5066/P9RIV03D.

Background: Invasive annual grasses are prevalent in the Great Basin of the United States. These grasses grow in the spring, mature in the summer, and die in the fall. Due to this cycle, invasive annual grasses contribute dry fuels, thereby aiding fire ignition and contributing to sagebrush ecosystem fragmentation.

Objectives: The authors aimed to provide a near-real-time estimate of annual herbaceous cover for 2018.

Methods: The authors used MODIS satellite imagery through July 1, 2018, ground-truth data of annual herbaceous percent cover, geophysical variables, and statistical software to estimate this second round of annual herbaceous cover at $250 \mathrm{~m}$ resolution (see the first round from Boyte and Wylie 2018 here; https://doi.org/10.5066/P9KSR9Z4). Areas above 2,250 m in elevation were not included in the modeling efforts.

Location: eastern California, Colorado, southern Idaho, southern Montana, western Nebraska, Nevada, eastern Oregon, western South Dakota, Utah, Wyoming

Findings: The authors created this percent-cover dataset across the Great Basin. Results for this dataset were similar to those of the earlier season dataset derived for May 2018 (Boyte and Wylie, 2018), with some individual pixel differences detected due to changing ground conditions. The authors identified cheatgrass as the most common annual grass in the study area, followed by red brome, medusahead, and ventenata.

Implications: These data can provide managers and scientists with spatially explicit near-real-time estimates of annual vegetation percent cover for management and research purposes. However, the authors note the large spatial scale of the dataset and the possibility of differences between this and other datasets with different spatial resolutions.

Topics: nonnative invasive plants; includes new geospatial data

\section{Boyte, S.P., and Wylie, B.K., 2019, Near-real-time herbaceous annual cover in the sagebrush ecosystem, USA, July 2019: U.S. Geological Survey data release.}

\section{DOI: https://doi.org/10.5066/P96PVZIF}

Background: Invasive annual grasses are prevalent in the Great Basin of the United States. These grasses grow in the spring, mature in the summer, and die in the fall. Due to this cycle, invasive annual grasses contribute fuels in the dry fall season, thereby aiding fire ignition and contributing to sagebrush ecosystem fragmentation.

Objectives: The authors aimed to provide a near-real-time estimate of annual herbaceous cover for 2019.

Methods: The authors used satellite imagery through July 1, 2019, ground-truth data of annual herbaceous percent cover, geophysical variables, and modeling software for this second-round ${ }^{1}$ of 2019 cover estimates at $250 \mathrm{~m}$ resolution. Areas above 2,250 $\mathrm{m}$ were not included in the modeling efforts.

Location: eastern California, Colorado, southern Idaho, southern Montana, western Nebraska, Nevada, eastern Oregon, western South Dakota, Utah, Wyoming

Findings: The authors created this percent cover dataset at $250 \mathrm{~m}$ resolution across the Great Basin. Results for this dataset were similar to those of the previous dataset derived for May 2019 (Boyte and Wylie, 2019, https://doi.org/10.5066/P9ZEK5M1), with some individual pixel differences due to changing ground conditions. The authors identified cheatgrass as the most common annual grass in the study area, followed by red brome, medusahead, and ventenata.

Implications: These data can provide managers and scientists with spatially explicit near-real-time estimates of annual vegetation cover for management and research purposes. However, the authors note the large spatial scale of the dataset and potential for differences between this and other datasets created at different resolutions.

Topics: nonnative invasive plants; includes new geospatial data

\footnotetext{
1Boyte, S.P., and Wylie, B.K., 2019, Early estimates of herbaceous annual cover in the sagebrush ecosystem (May 1, 2019): U.S. Geological Survey data release, https://doi.org/10.5066/P9ZEK5M1.
} 


\section{Clark, S.L., Da Silva, P.V., Dayan, F.E., Nissen, S.J., and Sebastian, D.J., 2019, The influence of winter annual grass litter on herbicide availability: Weed Science, v. 67, no. 6, p. 702-709.}

DOI: https://doi.org/10.1017/wsc.2019.45

Background: Invasive winter annual grasses such as downy brome, medusahead, and ventenata germinate in the fall, or opportunistically whenever growing conditions are ideal. Litter that accumulates from these invasive annual grasses promotes their spread by facilitating germination, increasing wildfire frequency, and impeding herbicide performance. Currently, little is known about how invasive grass litter depth and rain might impact different herbicides in their ability to reach the soil.

Objectives: The authors sought to (1) measure the amount of herbicide that reaches the soil through low and high litter levels, (2) determine the effectiveness of rainfall at removing herbicide from different litter types, and (3) determine if the effectiveness of rainfall at removing herbicides from litter changes over time.

Methods: The authors collected and dried downy brome, medusahead, and ventenata litter in August 2016. First, they applied the herbicides imazapic, indaziflam, and rimsulfuron to high- and low-litter conditions at three concentrations. Next, they repeated the experiment and simulated rainfall for each treatment. Finally, they applied four amounts of simulated rainfall to downy brome litter at three time intervals. After each experiment, the authors measured the amount of herbicide collected in clean glass dishes beneath the litter.

Location: Colorado, Idaho, Utah

Findings: Less herbicide reached the soil under high litter conditions for all three litter types. Downy brome prevented more herbicide from reaching the soil than litter from medusahead or ventenata. Litter type had no effect on the amount of herbicide that was able to be removed by simulated rainfall, though herbicide type did. The percentage of herbicide able to be removed from litter was greatest zero days after application and decreased over time, though the amount removed varied by herbicide.

Implications: The authors suggest that removing litter before herbicide treatment or applying soil active herbicides before predicted rainfall may increase the amount of herbicide reaching the soil and may improve management outcomes for control of invasive annual grasses. In instances where litter cannot be removed, the authors suggest using higher rates of herbicides.

Topics: nonnative invasive plants; weather and climate patterns; weed management; weed management subtopic: herbicides; water; soils or geology

\section{Davies, K.W., and Hamerlynck, E., 2019, Ventenata and other coexisting exotic annual grass control and plant community response to increasing Imazapic application rates: Rangeland Ecology and Management, v. 72, no. 4, p. 700-705.}

DOI: https://doi.org/10.1016/j.rama.2019.02.010

Background: Invasive annual grasses such as ventenata decrease native plant diversity, increase fire frequency, and decrease palatability of vegetation in rangelands. Although present in the Intermountain West since the 1950s, ventenata has recently been identified as a problem in rangelands. Herbicides, such as imazapic, have been used successfully to control invasive annual grasses, but imazapic has yet to be tested on the control of ventenata.

Objectives: The authors sought to (1) evaluate the effectiveness of different rates of imazapic application on controlling invasive annual grasses and (2) evaluate the subsequent native plant community response.

Methods: The authors applied four levels of imazapic four times to treatment blocks at two study sites during October 2014 and September 2015. The authors also included a "no treatment" block in the study. From June 2015 to 2017, the authors measured invasive annual grass and native vegetation density and cover to determine the impacts of the varying treatment levels.

Location: eastern Oregon 
Findings: All rates of imazapic treatment reduced invasive annual grass cover and density in the spring following treatments, with better control at higher application rates. No treatment level completely controlled ventenata, and invasive annual grass cover and density returned to pretreatment levels by the third year after treatment. For plants treated in 2014, perennial grass cover was greatest under the highest treatment application rate. Perennial grass density and forb cover and density were greater than pretreatment levels in 2016 but not during 2015 or 2017 and did not vary by treatment. In 2015 applications, perennial grass density and forb cover and density did not vary with treatment.

Implications: The authors suggest short-term or one-time applications of imazapic will likely not have a long-term impact on invasive annual grasses like ventenata. Revegetation, seeding native plants, and reducing annual grass litter could help increase native plant diversity, cover, and density when paired with imazapic treatments. Imazapic can likely treat ventenata infestation areas in the short term, but the authors note that for long-term control, more research is needed.

Topics: survival; nonnative invasive plants; weed management; weed management subtopic: herbicides

\section{Downing, W.M., Krawchuk, M.A., Coop, J.D., Meigs, G.W., Haire, S.L., Walker, R.B., Whitman, E., Chong, G., Miller, C., and Tortorelli, C., 2020, How do plant communities differ between fire refugia and fire-generated early-seral vegetation?: Journal of Vegetation Science, v. 31, no. 1, p. 26-39.}

DOI: https://doi.org/10.1111/jvs.12814

Background: Wildfires in the western United States are becoming more severe. Fires now often create large stand-replacing patches in which all or most of the overstory is killed. Examining differences in understories in severely burned and lightly burned areas will increase our understanding of dry forest ecosystems and their ability to maintain native biodiversity and resist exotic plant invasion, despite increasing fire severity.

Objective: The authors sought to compare the species diversity, community composition, and reproductive life-history traits of understory plant communities in lightly burned and stand-replacement areas.

Method: The authors mapped lightly burned areas and stand-replacement patches using aerial and satellite imagery. In the summer of 2017, they measured percent cover of vascular plants and environmental variables within 52 lightly burned and 135 stand-replacement plots across four areas that burned 12-17 years prior. Plots were in dry mixed-conifer forest, in areas with minimal management activity. The authors compared species diversity, community composition, and reproductive life-history traits between plot types.

Location: eastern Oregon

Findings: The authors found greater tree cover in lightly burned areas and greater shrub cover in stand replacement patches. They found similar herbaceous cover between plots. Plot types had similar plant communities and compositions and occurrence of invasive grasses such as cheatgrass and ventenata. The authors found more species than expected by chance only in unburned areas. While obligate seeding species were similar in abundance between plot types, resprouting and seed-banking species were more abundant in stand replacement patches.

Implications: The authors suggest plant communities in dry mixed-conifer forests may be resilient to fire. Lightly burned areas may aid in post-fire recovery by contributing seeds to areas with more severe fires. The authors note that lightly burned areas are not immune to invasive annual grasses postfire. There is no evidence to suggest that fires increase invasion potential within dry mixed-conifer forests in their study area. However, high severity fires carry other social and ecological threats, highlighting the importance of fuels reduction.

Topics: survival; dispersal, spread, vectors, and pathways; broad-scale habitat characteristics; fire; nonnative invasive plants; includes new geospatial data 


\title{
Endress, B.A., and Averett, J.P., 2019, Dataset of plant community composition in the Zumwalt Prairie Preserve, Oregon, USA: Data in Brief, v. 27, p. 104690.
}

\author{
DOI: https://doi.org/10.1016/j.dib.2019.104690
}

Background: Native prairie ecosystems are some of the most threatened in North America. The bunchgrass prairie in the northwestern United States, in particular, is one of the least studied ecosystems in North America.

Objectives: The authors sought to provide (1) maps, (2) plots, and (3) downloadable data files associated with Endress and others (2019), summarized in this annotated bibliography.

Methods: The authors sampled 123 grassland plots from 2008 to 2009. They measured percent cover, identified plant species, and statistically evaluated nonnative species in relation to plant community composition. They also determined the dominant species within the identified plant communities.

Location: northeastern Oregon

Findings: The authors provided maps, plots, and data related to nonnative species and community composition in their study area.

Implications: The authors state that these data provide information for a relatively new invasive species, ventenata. These data may be used for comparison of future nonnative invasive plant research, such as tracking long-term ecosystem trends.

Topics: site-scale habitat characteristics; nonnative invasive plants; protected lands or areas; includes new geospatial data

\section{Endress, B.A., Averett, J.P., Naylor, B.J., Morris, L.R., and Taylor, R.V., 2020, Nonnative species threaten the biotic integrity of the largest remnant Pacific Northwest bunchgrass prairie in the United States: Applied Vegetation Science, v. 23, no. 1, p. 53-68.}

\section{DOI: https://doi.org/10.1111/avsc.12464}

Background: Historical and current anthropogenic stressors have reduced the extent of the Pacific Northwest bunchgrass ecosystem, one of the most endangered grasslands on Earth. A better understanding of the factors that influence communitylevel patterns of invasive plants is critical to the development of an effective conservation approach for the ecosystem.

Objectives: The authors' objectives were to (1) identify distinct plant communities within the study area, (2) determine the most widespread and abundant nonnative species and how their composition varies across communities, and (3) understand how historic land use, biotic, and environmental factors influence invaded plant-community composition.

Methods: The authors assessed plot-level land use history through aerial photography and performed point-intercept surveys in a protected area from June to August in 2008-09. Using species-level data from 96 uncultivated plots and 27 old fields, they identified biologically meaningful communities. They used multiple techniques to link land use, biological, and environmental variables to community composition and species abundance.

\section{Location: northeastern Oregon}

Findings: The authors identified three primary plant communities: the old field community, dominated by nonnative perennial grasses; the mesic prairie community, dominated by native perennial species; and, the xeric prairie community, dominated by ventenata. Across all plots, ventenata was the most abundant nonnative species, while annual bromes, including cheatgrass, field brome, and soft brome were the most frequently encountered nonnative grasses. Ventenata was highly associated with xeric habitats, while nonnative perennial grasses were associated with previously cultivated plots. Data are provided in Endress and Averett (2019) and summarized in this annotated bibliography.

Implications: The abundance of nonnative perennial grasses within previously cultivated areas suggests persistent effects of land-use history. Although most abundant on xeric plots, ventenata was widespread and may be able to move into wetter areas. Field brome and soft brome were found throughout the study area, which suggests they may not require recent disturbance to persist given current conditions. Given its current abundance and ability to colonize a range of habitats rapidly, ventenata poses a serious threat to endangered grasslands.

Topics: site-scale habitat characteristics; habitat restoration or reclamation; nonnative invasive plants; agriculture; weather and climate patterns; protected lands or areas; includes new geospatial data 


\title{
Ingwell, L.L., and Bosque-Pérez, N.A., 2015, The invasive weed Ventenata dubia is a host of barley yellow dwarf virus with implications for an endangered grassland habitat: Weed Research, v. 55, no. 1, p. 62-70.
}

\author{
DOI: https://doi.org/10.1111/wre.12110
}

Background: Barley yellow dwarf virus is transmitted through aphids and can negatively impact native plant species, such as those found in the endangered Palouse Prairie ecosystem. Economic losses due to this virus can be significant. Invasive annual grasses have become one of the main threats to Palouse Prairie, but their role in transporting and hosting this virus has not been determined.

Objectives: The authors aimed to determine (1) whether ventenata in prairie and Conservation Reserve Program fields host barley yellow dwarf virus, (2) whether ventenata can be infected with the virus, (3) whether ventenata can be an infection source, and (4) the impact of the virus on ventenata growth.

Methods: The authors surveyed 11 sites in spring or early summer of 2011 and 2012 for ventenata, collecting up to 15 samples per survey. In the laboratory, they grew ventenata from northern Idaho seeds and then exposed these and native barley to viruspositive and virus-negative aphids. The authors exposed virus-negative aphids to infected ventenata plants and then transferred these aphids to noninfected barley. They tested the exposed and control plants for virus genetic material to determine whether plants became infected. Finally, the authors measured height, number of leaves, tillers (new shoots), and weight of infected ventenata plants.

Location: western Idaho, eastern Washington

Findings: The authors identified and collected ventenata from a total of six sites in 2011 and four sites in 2012, with a total of eight surveyed sites as collection locations. They identified barley yellow dwarf virus in 11-87 percent of samples, depending on site and year. All laboratory-grown ventenata exposed to infected aphids tested positive for the virus. With ventenata as a virus source, 94 percent of barley became infected. Infected ventenata had lower height, fewer leaves and tillers, and reduced aboveground dry weight compared to noninfected ventenata plants.

Implications: This is the first report of barley yellow dwarf virus in this area and of ventenata as a host and vector. This virus may facilitate invasive grass spread by reducing fitness of neighboring native plants. The authors suggest further study to determine how the virus impacts ventenata invasiveness, whether prairie native grasses are impacted, and aphid preferences for ventenata.

Topics: dispersal, spread, vectors, and pathways; other: species and population characteristics; nonnative invasive plants

\section{Jones, L.C., Norton, N., and Prather, T.S., 2018, Indicators of ventenata (Ventenata dubia) invasion in sagebrush steppe rangelands: Invasive Plant Science and Management, v. 11, no. 1, p. 1-9.}

DOI: https://doi.org/10.1017/inp.2018.7

Background: Ventenata reduces forage production and displaces species within grassland ecosystems. It is expanding further into sagebrush steppe ecosystems, though little is known about its current distribution, abundance, and habitat niche within these landscapes. Such information is critical in predicting how ventenata might spread in the future and understanding how to better protect native plant communities.

Objectives: The authors sought to determine (1) the distribution and abundance of ventenata within sagebrush rangelands, (2) how the presence of ventenata might impact native plant diversity and abundance, and (3) the biotic and abiotic factors associated with ventenata presence and abundance.

Methods: In June of 2015, the authors used local knowledge to select 15 field sites based on their representation of the dominant plant community and ventenata presence in areas known to support sagebrush steppe. They measured soil depth, chemical composition, percent cover of vascular plants, biological soil crust, bare ground, rock cover, and leaf litter at randomly chosen plots within each site. The authors then calculated plot-level species richness and diversity, explored trends with abiotic factors, and evaluated potential indicator species. 
Location: eastern Oregon, southwestern Idaho

Findings: Ventenata occurred at approximately half of plots across all sites and was primarily found in moist habitats. Native species richness and overall species richness and diversity were lower at sites with high ventenata cover. Native species diversity was not related to ventenata cover. Ventenata was positively associated with clay soils and negatively associated with soil phosphorous and potassium concentrations. Medusahead was positively correlated with ventenata presence.

Implications: Ventenata is in an early stage of invasion within sagebrush rangelands. The authors suggest that managers should focus survey efforts on moist or wet habitats where ventenata infestations initiate. The authors also suggest that medusahead is a strong indicator species for ventenata, and that habitats where medusahead has previously established are susceptible to ventenata invasion.

Topics: population estimates or targets; dispersal, spread, vectors, and pathways; site-scale habitat characteristics; habitat selection; nonnative invasive plants

\title{
Kerns, B.K., Tortorelli, C., Day, M.A., Nietupski, T., Barros, A.M.G., Kim, J.B., and Krawchuk, M.A., 2020, Invasive grasses-A new perfect storm for forested ecosystems?: Forest Ecology and Management, v. 463, p. 117985.
}

\author{
DOI: https://doi.org/10.1016/j.foreco.2020.117985
}

Background: Invasive grasses are globally widespread and are well known to alter disturbance regimes in semiarid and arid ecosystems. However, the effects of invasive grasses in forested systems are not well understood. The establishment of invasive grasses in forested ecosystems could, in tandem with other factors, create a critical situation leading to persistent state change that includes the potential for transition to nonforested vegetation types.

Objectives: The authors sought to (1) provide background information on invasive grasses in forests and (2) describe potential factors that could interact with grass invasion and lead to a "perfect storm" scenario for forested ecosystems.

Methods: The authors reviewed literature focusing on three key components that could interact with invasive grasses in forested ecosystems: (1) climate change, (2) wildfire and grass-fire cycles, and (3) overstory management. They also presented a case study of the potential impacts of ventenata in forested ecosystems.

Location: North America

Findings: Although invasive grasses were generally believed to be shade intolerant, there is evidence that some species may be able to establish in the cooler, light-limited habitats of forest ecosystems or within canopy gaps. Ventenata has been reported in low-biomass habitats that were thought to be invasion resistant. Warmer temperatures and increased carbon dioxide due to climate change may facilitate exotic grass invasion at the expense of native species. The invasion of exotic grasses in forested systems can alter the fire regime by increasing biomass and connectivity of fuels. Invasive grasses also have rapid post-fire recovery which may lead to shorter fire return intervals in disturbed areas and potential state change to nonforested vegetation types. Finally, management practices that disturb ground and create gaps may promote invasive grasses, which could contribute to increased surface fire behavior in invaded shrublands and grasslands.

Implications: The authors suggest that mitigation measures such as (1) recognition of the potential for invasive grasses to impact forested systems, (2) development of specific management strategies for invasive grass species, (3) mapping and monitoring of invasive grass populations, and (4) exploring tradeoffs of management actions may reduce impacts of invasive grasses in forested systems.

Topics: dispersal, spread, vectors, and pathways; habitat restoration or reclamation; nonnative invasive plants; fire; fuels and fuels management; climate change; weed management; weed management subtopic: cultural control 


\section{Koby, L.E., Prather, T.S., Quicke, H., Beuschlein, J., and Burke, I.C., 2019, Management of Ventenata dubia in the inland Pacific Northwest with indaziflam: Invasive Plant Science and Management, v. 12, no. 4, p. 223-228.}

DOI: https://doi.org/10.1017/inp.2019.26

Background: Noncropland areas of the inland Pacific Northwest are diverse and include endangered prairie ecosystems. These noncropland areas provide diversity, wildlife habitat, and soil conservation but are threatened by ventenata, which displaces desirable vegetation by establishing itself during fall or early spring when perennial grass species are dormant. Treatments that include preemergent herbicides may effectively control ventenata beyond the year of application without harming desirable vegetation.

Objectives: The authors' objective was to assess the effect of an early-season application of indaziflam on ventenata-invaded grassland communities in comparison to other common herbicides.

Methods: The authors established two study sites and applied herbicidal treatments in early spring 2016. Treatments included application of indaziflam, rimsulfuron, imazapic, and glyphosate applied at variable rates and combinations. They visually estimated average cover of each species the summer after application and again 16 months after treatment to assess effects on abundance and diversity over time. They also collected aboveground biomass samples 17 months after treatment.

Location: western Idaho, eastern Washington

Findings: The summer following application, ventenata cover was reduced by all treatments except glyphosate alone. There were significant site differences for perennial grass cover, but indaziflam treatments were associated with increased perennial grass cover. Indaziflam treatment reduced ventenata cover 16 months after application compared to all other treatments. Indaziflam application reduced biomass of ventenata and increased biomass of perennial grasses.

Implications: Indaziflam treatment was successful at controlling ventenata in the year of application and for more than 1 year following treatment while avoiding significant impacts on desirable perennial vegetation. However, the authors note that their study sites were degraded, with little species diversity, and dominated by nonnative species, and that further examination is needed in more diverse landscapes. The authors suggest that the application of indaziflam in mixture with post-emergent herbicides may help prevent further spread of ventenata.

Topics: survival; nonnative invasive plants; weed management; weed management subtopic: herbicides

\section{McKay, S., Morris, L.R., Morris, C.E., and Leger, E.A., 2017, Examining the potential competitive effects of Ventenata dubia on annual and perennial grasses: Prairie Naturalist, v. 49, p. 19-22.}

Background: Ventenata is an invasive annual grass that has been in the United States since 1952, where it was first reported in Washington. It has since spread to seven other states throughout the west, as well as Canada. Currently, little is known about the life history of ventenata, or how it might affect the ecology of native plant communities through competitive interactions.

Objectives: The authors sought to determine if ventenata has competitive interactions with two other invasive annual grasses (cheatgrass and medusahead) and one native perennial grass (bluebunch wheatgrass).

Methods: In 2014, the authors collected soil, cheatgrass seeds, and medusahead seeds from the field and purchased bluebunch wheatgrass seeds from a seed supplier. In a greenhouse experiment, they grew each species in combination with the others and separately as controls, with 20 replicates each. The authors calculated time until emergence and percent emergence of each species. When plants showed signs of reproductive shoots, they were harvested, dried, and weighed to determine biomass. Finally, the authors compared outcomes from plants grown separately to plants grown in competition with ventenata.

Location: northeastern Oregon 
Findings: Cheatgrass had the highest percent emergence, while ventenata had the lowest percent emergence and emerged later than the other species. Ventenata did not have competitive effects on cheatgrass or medusahead, which showed no reduction in biomass or species performance when grown with ventenata. However, ventenata did have competitive effects on bluebunch wheatgrass, which showed a decrease in species performance and a 20 percent reduction in biomass when grown with ventenata.

Implications: This study suggests that ventenata may have a greater competitive effect at the seedling stage on native perennial grasses such as bluebunch wheatgrass than it has on other invasive annual grasses. The authors note that this may be due to ventenata and bluebunch wheatgrass occupying the same root space or emerging at similar times and that further research should investigate the growth dynamics and phenology of ventenata.

Topics: survival; behavior or demographics; nonnative invasive plants

\section{McCurdy, D.E., Watts, C.J., Chibisa, G.E., Prather, T.S., and Laarman, A.H., 2017, Feed processing affects palatability of ventenata-infested grass hay: Journal of Animal Science, v. 95, no. 4, suppl_4, p. 146.}

DOI: https://doi.org/10.2527/asasann.2017.295

Background: Infestation of ventenata in rangelands is linked to declines in forage production and can have negative economic consequences. The palatability of ventenata for livestock is poor. However, ventenata has similar crude protein content and digestibility compared to other forages like cheatgrass.

Objectives: The authors sought to investigate the palatability of ventenata based on its texture and surface-bound microbes.

Methods: The authors provided access to a reference feed bunk and one of five treatment feed bunks for each of 35 calves for a period of 7 days. The reference diet was mixed grass hay, and the treatment diets consisted of ventenata-infested hay, autoclaved mixed grass hay, autoclaved ventenata-infested hay, pelleted ventenata-infested hay, and a control of mixed grass hay. The authors weighed all calves on day 1 and again on day 7 to measure the change in overall body weight. They also assessed calf preference for the treatment diet in comparison with the reference diet.

Location: Unspecified

Findings: Across treatments, the calves experienced no difference in weight gain over the course of the experiment. The calves showed preference for the reference diet over ventenata-infested hay, and the autoclaved ventenata-infested hay treatment did not improve palatability. However, the calves showed equal preference for the mixed grass hay reference diet and the pelleted form of ventenata-infested hay.

Implications: The authors suggest that the calves' equal preference for pelleted ventenata-infested hay and mixed grass hay is evidence that the poor palatability of ventenata may be due to its texture. Feed processing may improve the palatability of ventenata.

Topics: nonnative invasive plants; grazing/herbivory

\section{Nicolli, M., Rodhouse, T.J., Stucki, D.S., and Shinderman, M., 2020, Rapid invasion by the annual grass Ventenata dubia into protected-area, low-elevation sagebrush steppe: Western North American Naturalist, v. 80, no. 2, p. 243-252.}

DOI: https://doi.org/10.3398/064.080.0212

Background: Even in protected areas, sagebrush steppe ecosystems are threatened by invasions of nonnative annual grasses. Xeric low-elevation steppes are known to have low fire resilience and exhibit vulnerability to annual grass invasion. However, they are not known to be susceptible to ventenata, a well-established nuisance in mesic ecosystems of the northwest.

Objectives: The authors aimed to use field monitoring data to revisit assumptions about ventenata occurrence on the xeric lowelevation steppe. 
Methods: The authors began monitoring live foliar cover in a national monument in 2008 but focused their analysis on 1,854 plots monitored during 2016-19. Study site locations were determined using soil survey polygons; steep slopes and fossilbearing ash beds were excluded from analysis. The authors evaluated ventenata occurrence by cover class based on elevation, topographic position, and mean monthly water balance deficit.

Location: central Oregon

Findings: This study first identified ventenata in the study area in summer 2014, which is one of the first documentations of the species in the area. The authors found that invasion increased during the 4-year study period and that ventenata spread occurred during relatively wet winters.

Implications: This study provides evidence that ventenata has begun to invade the sagebrush steppe and has the potential to greatly affect species composition and threaten the ecological integrity of this system. The findings support the hypothesis that ventenata establishes and spreads in wetter sites and during wetter winters in xeric sagebrush steppe, suggesting that access to local-scale weather predictions will be important for management. The authors also suggest that their findings provide evidence for an alternative state-transition pathway of historic communities to other nonnative grass species rather than cheatgrass.

Topics: behavior or demographics; dispersal, spread, vectors, and pathways; site-scale habitat characteristics; nonnative invasive plants; fire; weather and climate patterns; protected lands or areas

\section{Nyamai, P.A., Prather, T.S., and Wallace, J.M., 2011, Evaluating restoration methods across a range of plant communities dominated by invasive annual grasses to native perennial grasses: Invasive Plant Science and Management, v. 4, no. 3, p. 306-316.}

DOI: https://doi.org/10.1614/IPSM-D-09-00048.1

Background: Prairies and grasslands of the Pacific Northwest are some of the most imperiled habitats in North America, largely due to conversion to agriculture. Successful restoration of prairie ecosystems relies on the establishment of native perennials, possibly in conjunction with weed control. Availability of seed and suitable microsites, important to native species recruitment, can be increased by mulching to protect seeds and retain moisture.

Objectives: For three grass communities, the authors sought to (1) assess the impact of restoration treatments on nonnative and native plants, (2) assess the effect of seed predation and soil moisture on native plant establishment across treatments, and (3) identify appropriate restoration approaches for each community.

Methods: Within two prairie remnants in 2008, the authors applied experimental treatments in 144 plots in three grass communities: predominately nonnative annual (mainly cheatgrass and ventenata), mixed, and predominately native perennial. After raking to reduce litter, the experimental treatments included a control and five treatments involving combinations of spot or broadcast herbicide application, seeding of native forbs and perennial grasses, and mulching. The authors measured percent foliar cover, plant density, soil moisture, and seed predation within each plot and used statistical analyses to determine impacts of treatments on plant communities.

Location: western Idaho

Findings: Annual grass cover reduction was highest in the annual and mixed plant communities and in treatments that included broadcast herbicide treatments. Perennial grass density was higher in treatments involving herbicide or seeding and mulching. Overall, seed predation was high, but was lower in plots treated with broadcast herbicide plus seeding and mulching. Seeding alone did not support greater recruitment and soil moisture was higher at mulched sites.

Implications: The authors suggest that herbicide was successful in reducing annual grasses given the reduction in grass cover following treatment. Mulch was an important component to restoration as it retained moisture, supported higher germination rates, and may discourage seed predation when used. Managers need to consider local plant communities and the timing and application method of herbicide to effectively control annual grasses without negatively impacting native species. Additionally, the authors created a decision-support tool for managers to use for management of annual grasses in prairies.

Topics: behavior or demographics; site-scale habitat characteristics; habitat restoration or reclamation; predators or predator control; nonnative invasive plants; weed management; weed management subtopic: herbicides 


\title{
Pervukhina-Smith, I., Sforza, R.F.H., Cristofaro, M., Smith, J.F., and Novak, S.J., 2020, Genetic analysis of invasive populations of Ventenata dubia (Poaceae)—An assessment of propagule pressure and pattern of range expansion in the Western United States: Biological Invasions, v. 22, no. 12, p. 3575-3592.
}

\author{
DOI: https://doi.org/10.1007/s10530-020-02341-2
}

Background: Identifying new potentially invasive plant species and the native communities which may be impacted is critically important to mitigate new invasions. Genetic techniques can identify a species' invasion potential (or propagule pressure) quantified by the number of release events and the number and genetic diversity of individuals released. Ventenata has displayed invasive capacity throughout the western United States, but its invasion potential has yet to be genetically assessed.

Objectives: The authors sought to assess ventenata's (1) introduction dynamics and propagule pressure, (2) pattern of range expansion, and (3) genetic diversity within and among invasive populations.

Methods: The authors consulted historic herbarium records of ventenata collected from the western United States. In addition, from 2014 to 2016, they collected 27-40 samples from 51 populations across ventenata's western range. The authors stored the ventenata seeds for 3 months and then allowed the seeds to germinate and grow. Using these plants, the authors assessed withinpopulation genetic diversity and among-population genetic diversity using a variety of genetic and statistical analyses.

Location: California, Idaho, Montana, Nevada, Oregon, Washington, Wyoming, Utah

Findings: Herbarium and genetic data indicate multiple introductions and moderate propagule pressure (moderate number of individuals, invasion events, or genetic variability). From herbarium collections, the authors identified the earliest collected ventenata record from western Washington in 1952, followed by records collected from western Idaho and south-central Washington. They identified an increase in samples across eight states in the 1990s. Ventenata genetic diversity was low within populations and high between populations. Columbia Basin populations had the highest genetic diversity, and Rocky Mountain populations had the lowest genetic diversity. Most genetic diversity across all populations could be attributed to differences between ventenata populations, and the authors identified four major genetic groups across all 51 populations.

Implications: The authors report that these genetic results are similar to those seen for cheatgrass and medusahead. Overall, ventenata genetic diversity was low in comparison with other plant species, which may be attributed to its high rate of selfmating. However, low diversity did not limit the rapid spread of ventenata. Genetic data from native populations could help explain patterns of post-introduction spread and inform management.

Topics: genetics; dispersal, spread, vectors, and pathways; nonnative invasive plants

\section{Rinella, M.J., Bellows, S.E., and Roth, A.D., 2014, Aminopyralid constrains seed production of the invasive annual grasses medusahead and ventenata: Rangeland Ecology and Management, v. 67, no. 4, p. 406-411.}

DOI: https://doi.org/10.2111/REM-D-13-00138.1

Background: Invasive annual grasses, such as medusahead and ventenata, reduce native species diversity, alter nutrient cycles, and increase fire frequency in native grasslands. Commonly used herbicides in invasive grass management can also damage native plants. Aminopyralid, a growth regulating herbicide, is less harmful to perennial native grasses than some commonly used herbicides, but its effectiveness in preventing seed production of ventenata and medusahead has yet to be evaluated.

Objectives: The authors evaluated the effects of multiple application rates of two growth regulating herbicides on (1) seed production and (2) biomass of ventenata and medusahead.

Methods: In July 2010, the authors collected medusahead and ventenata seeds and planted them in a climate-controlled greenhouse. At three growth stages (seedling, preflowering, and flowering), they applied two rates of aminopyralid and picloram herbicides to medusahead and one rate to ventenata. The authors harvested seeds, tested them for viability, and dried and weighed the plants. Finally, they modeled the impacts of application rate and growth stage on seed production and biomass. In all experiments, the authors included a nontreated control. 
Location: eastern Oregon

Findings: All applications of aminopyralid and picloram reduced medusahead seed production. Aminopyralid applied during the prehead and flowering stages reduced seed production by 96-100 percent, but picloram was not as effective. For ventenata, aminopyralid was more effective than picloram, but herbicides did not consistently reduce seed production. The greatest application rate of herbicide reduced medusahead biomass when applied at seedling stage. Ventenata biomass did not vary with treatments but was slightly lower when herbicides were applied at the seedling stage, although this finding was not statistically significant.

Implications: Because growth regulating herbicides applied postemergence impact grass seed production, they may be less harmful to perennial grasses which rely on vegetative propagation (compared to glyphosate or imazapic). These herbicides could be effective on other nonnative annual grasses as well, though more research is needed to determine effective treatments for ventenata. As growth regulators can damage native forbs and shrubs and likely reduce seed production of native annual grasses, the authors suggest using caution when using growth regulator herbicides in the field.

Topics: behavior or demographics; nonnative invasive plants; weed management; weed management subtopic: herbicides

\section{Sebastian, D.J., Nissen, S.J., and Rodrigues, J.D., 2016, Pre-emergence control of six invasive winter annual grasses with imazapic and indaziflam: Invasive Plant Science and Management, v. 9, no. 4, p. 308-316.}

DOI: https://doi.org/10.1614/IPSM-D-16-00045.1

Background: There are several invasive annual grass species that pose a threat to the integrity of native perennial plant communities within sagebrush ecosystems. Current herbicide treatments lack the residual control needed to prohibit rapid reinvasion of invasive plants from seedbanks, making restoration efforts difficult. Indaziflam is a new herbicide treatment that may provide residual weed control and be helpful in creating an effective, long-term solution to invasive annual grass management.

Objectives: The authors aimed to compare the activity of two herbicides, imazapic and indaziflam, on several species of invasive annual grasses found in the western United States.

Method: In 2014, the authors collected seeds from six invasive annual grasses: downy brome, feral rye, Japanese brome, jointed goatgrass, medusahead, and ventenata. Twice in 2015 they set up a greenhouse experiment where each species was given six herbicide application rates as well as a control, each with three replicates. Four weeks after herbicide treatment, the authors harvested, dried, and weighed aboveground plant biomass. Finally, they modeled the rates at which herbicide application resulted in a 50 percent reduction of plant biomass.

Location: California, Colorado, Idaho

Findings: Indaziflam was significantly more active than imazapic against downy brome, feral rye, Japanese brome, medusahead, and ventenata. Japanese brome was the most sensitive species to both indaziflam and imazapic. Jointed goatgrass showed the least sensitivity to indaziflam, and feral rye showed the least sensitivity to imazapic. The 50 percent reduction in biomass values for ventenata was 16 times lower with indaziflam than with imazapic and 6 times lower for medusahead.

Implications: The authors note that indaziflam appears to be more potent than imazapic against the invasive annual grasses tested. They also suggest that the longer soil half-life and lower water solubility of indaziflam may cause it to provide several years of residual control after initial treatment, which may aid in restoration efforts of native perennial species. Further research under field conditions is necessary to determine real-world effectiveness of indaziflam.

Topics: behavior or demographics; nonnative invasive plants; weed management; weed management subtopic: herbicides 


\title{
Tortorelli, C., Krawchuk, M., and Kerns, B., 2020, Expanding the invasion footprint-Ventenata dubia and relationships to wildfire, environment, and plant communities in the Blue Mountains of the Inland Northwest, USA: Applied Vegetation Science, v. 23, no. 4, p. 562-574.
}

\author{
DOI: https://doi.org/10.1111/avsc.12511
}

Background: Invasive grasses can have negative impacts on natural fire cycles throughout native grasslands and shrublands in the United States. Recently, systems not previously impacted by invasive grasses are showing increased susceptibility to ventenata invasion. Given ventenata's relatively new status, its impact on fire cycles and community composition remains relatively unknown.

Objectives: The authors sought to (1) identify ventenata habitat characteristics and determine how these compare to cheatgrass and medusahead and (2) determine how fire impacts the relationship between ventenata and native plant communities.

Methods: From May to August 2018, the authors measured soil, vegetation, and environmental factors in burned and unburned plots within and surrounding seven recently burned areas, in a region of known ventenata occurrence. They incorporated these data with estimates of burn severity of each plot and with climate data. The authors then identified features associated with ventenata, cheatgrass, and medusahead presence and modeled the impact of ventenata on native species diversity and richness in burned and unburned plots.

Location: eastern Oregon

Findings: The authors found that (1) ventenata and cheatgrass were associated with different plant communities and (2) ventenata and medusahead were more alike in their plant community associations at low elevations but ventenata invaded communities at higher elevations. Ventenata was associated with a variety of cover types and was more prevalent in rocky and bare soils than medusahead or cheatgrass. Native plant diversity decreased in burned and unburned plots where ventenata was present but decreased more strongly in unburned plots. Native plant richness varied in unburned plots with ventenata present and decreased with increasing ventenata abundance in burned plots.

Implications: Ventenata may be able to take advantage of soil conditions in burned and bare areas where native species are absent and may outcompete native species postfire. Unlike cheatgrass and medusahead, ventenata may tolerate higher elevations and invade communities previously resistant to invasive grasses. Communities with diverse native species, especially those with high perennial forb cover, may be more resistant to ventenata invasion after fire. Post-fire invasions of ventenata during the summer may indicate that prescribed burns during summer may not be an effective control strategy against ventenata.

Topics: site-scale habitat characteristics; habitat selection; fire; weed management; weed management subtopic: cultural control; nonnative invasive plants; includes new geospatial data

\section{Wallace, J.M., Pavek, P.L.S., and Prather, T.S., 2015, Ecological characteristics of Ventenata dubia in the Intermountain Pacific Northwest: Invasive Plant Science and Management, v. 8, no. 1, p. 57-71.}

DOI: https://doi.org/10.1614/IPSM-D-14-00034.1

Background: The invasive annual grass, ventenata, has expanded over the past decade in many habitats in the Intermountain West. Ventenata has only recently begun to have a negative economic impact on hay production and grazing systems. Increasing knowledge of ventenata life history patterns will enhance management effectiveness.

Objectives: The authors' objectives were to (1) expand on dormancy and germination knowledge, (2) determine seed bank persistence, (3) evaluate seedling emergence and survival, and (4) evaluate seedling emergence and phenological development of ventenata in three habitats.

Location: northern Idaho, northeastern Oregon, eastern Washington 
Methods: The authors ran experiments from 2009 to 2013. In the laboratory, they explored how the duration of afterripening (a period of dry storage used to promote germination), cold exposure, and seed age affect germination rates. They also examined the impact of temperature on seeds stored for 4 months. In the field, they studied the impacts of seed burial depth and duration on the persistence of the seed bank, analyzed how litter amounts affected seedling emergence, and explored the effect of habitat type on phenology and growth of seedlings.

Findings: The authors found germination rate was positively affected by storage time and negatively affected by cold exposure. Seeds germinated under a wide variety of temperatures. Germination rates were high at any soil depth after 1 month. Shallow seeds germinated for up to 3 years, but deep seeds did not germinate after 1 year. Litter positively influenced seedling emergence and survival, but tillering (production of new shoots) was higher in the no-litter treatments. Average emergence occurred between mid-October and mid-November across habitats and years, but emergence in hay systems occurred in the spring.

Implications: Due to ventenata's phenological timing and its ability to germinate poststorage, there is likely mature seed in hay bales that are regionally transported in July. Cumulative precipitation may be an indicator of ventenata emergence. Applying herbicides in late fall after emergence could be effective, but effectiveness of spring herbicide application could depend on soil properties. The authors suggest using soil and moisture data to time emergence for herbicide applications. They also suggest that controlled burns could help reduce litter, which may reduce seedling recruitment.

Topics: survival; behavior or demographics; captive breeding; dispersal, spread, vectors, and pathways; nonnative invasive plants; fire; weed management; weed management subtopic: cultural control; weather and climate patterns

\section{Wallace, J.M., and Prather, T.S., 2016, Herbicide control strategies for Ventenata dubia in the Intermountain Pacific Northwest: Invasive Plant Science and Management, v. 9, no. 2, p. 128-137.}

DOI: https://doi.org/10.1614/IPSM-D-16-00017.1

Background: Ventenata has recently become a pest within the grassland ecosystems of the Intermountain Pacific Northwest. Ventenata invasion can lead to soil erosion, damage remnant prairie patches, facilitate the spread of pathogens to crops, and decrease hay production. To be most effective, treatment must control ventenata while promoting the growth of desirable species.

Objectives: The authors aimed to (1) evaluate several herbicides for control of ventenata and to determine the tolerance of resident perennial grasses to these herbicides, and (2) evaluate the responses of ventenata and perennial grasses to fertilizer treatment, with and without herbicides, across sites with variable perennial grass composition.

Methods: In the first study, the authors applied six herbicide treatments at four sites with different primary grass species in fall 2011. Two sites received preemergent and early postemergent treatment and two sites received only postemergent treatment. In the second study, during spring 2012 and fall 2013, the authors applied seven fertilizer treatments with and without herbicide across three sites with different perennial grass species. One site received preemergent treatment and two sites received early postemergent treatment. The authors estimated coverage of ventenata and perennial grasses at fixed intervals following treatment.

Location: western Idaho, eastern Washington

Findings: The authors found that both herbicide application times were effective at controlling ventenata, but that control was influenced by an interaction between herbicide type and application timing. Timing of application and herbicide treatment had variable effects on perennial grasses, with some combinations producing noticeable damage and others negligible effects. Ventenata coverage increased or did not differ from an untreated control at all sites 21 months following herbicide application. The authors found that spring applications of nitrogen and of phosphorous and potassium applications without herbicide treatment reduced ventenata cover due to increased competitiveness of perennial grasses.

Implications: The authors suggest that preemergent applications of rimsulfuron and flufenacet plus metribuzin and early postemergent application of rimsulfuron and sulfosulfuron provided consistent control of ventenata. They noted that sulfosulfuron damaged timothy and smooth brome and stress that label restrictions and perennial grass tolerance should guide herbicide treatments. They also suggest that spring application of fertilizers can help control ventenata.

Topics: survival; nonnative invasive plants; weed management; weed management subtopic: herbicides 
Denver Publishing Service Center

For more information concerning the research in this report, contact the

Center Director, USGS Fort Collins Science Center

2150 Centre Ave., Bldg. C

Fort Collins, CO 80526-8118

(970) 226-9100

Or visit the Fort Collins Science Center website at: https://www.usgs.gov/centers/fort 


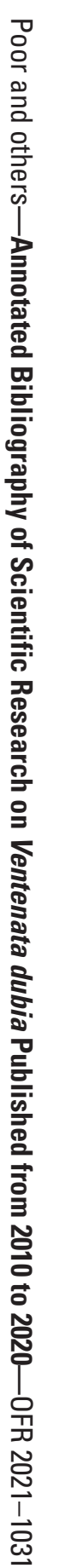

